http://kitaibelia.unideb.hu/

ISSN 2064-4507 (Online) • ISSN 1219-9672 (Print)

(C) Department of Botany, University of Debrecen, Hungary

26(1): 21-30.; 2021

DOI: $10.17542 /$ kit.26.21

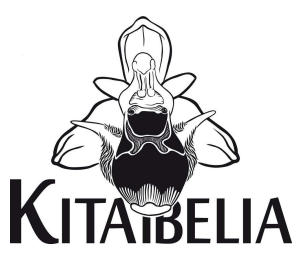

\title{
Néhány kiegészítés a Jászság flórájához
}

MolnÁr Csaba

H-3728, Gömörszőlős, Kassai u. 34.; birkaporkolt@yahoo.co.uk

\section{Additions to the flora of Jászság (Central Hungary)}

\begin{abstract}
Within the framework of the Hungarian Flora Mapping Program, nine quadrants were surveyed in the territory of Jászság in 2012 and 2020. Regionally important floristic records of 68 vascular plant species are presented in this paper. Some of them are aliens (e.g., Alopecurus myosuroides, Amaranthus deflexus, Juncus tenuis, Phytolacca esculenta) or rare native weeds (e.g., Aegilops cylindrica, Bupleurum affine, Myagrum perfoliatum). Records of regionally (e.g., Coronopus squamatus, Linaria biebersteinii) or nationwide (Silene bupleuroides) rare native species as well as indicators of former forests (e.g., Clematis recta, Elymus caninus, Melica altissima, Sisymbrium strictissimum) are also presented. An interesting road edge rich in saline species (Artemisia santonicum, Chenopodium chenopodioides, Hordeum hystrix, Plantago maritima) is discussed in detail.
\end{abstract}

Keywords: alien species, flora mapping, flora of Hungary, Jászság, rare species

Összefoglalás - Magyarország Flóratérképezési Programja során 2012-ben 9 kvadrát felmérését végeztem el a Jászságban. Az adatgyűjtést 2020-ban kiegészítettem. Cikkemben az érdekesebb, regionálisan fontos florisztikai adatokat közlöm 68 edényes növényfajra vonatkozóan. Közöttük vannak idegenhonos taxonok (pl. Alopecurus myosuroides, Amaranthus deflexus, Juncus tenuis, Phytolacca esculenta) országosan (Silene bupleuroides), vagy regionálisan ritka fajok (pl. Coronopus squamatus, Linaria biebersteinii), a térség egykori erdeinek túlélői (pl. Clematis recta, Elymus caninus, Melica altissima, Sisymbrium strictissimum) és ritka gyomok (pl. Aegilops cylindrica, Bupleurum affine, Myagrum perfoliatum). Bemutatok egy szikes fajokban gazdag múút menti padkát is (Artemisia santonicum, Chenopodium chenopodioides, Hordeum hystrix, Plantago maritima).

Kulcsszavak: flóratérképezés, idegenhonos fajok, Jászság, Magyarország flórája, ritka fajok

\section{Bevezetés}

Változó, jellegtelenedő világunkban különösen fontos az élővilág átalakulásának nyomon követése. A még megmaradt túlélők, az új környezethez is alkalmazkodók, illetve a terjedő jövevények térképezése segít áttekinteni a helyzetünket. A 2002-2015 között zajlott Magyarországi Flóratérképezési Program egyfajta egységes módszertan szerint készült alapállapotfelvételnek tekinthető. Munkámat ennek keretei között végeztem.

\section{Anyag és módszer}

2012 júliusában és augusztusában 9, a Jászság térségében lévő flórakvadrát felmérését végeztem el. Egy kvadrát a Jászság északnyugati részén, Jászfényszaru körül van, míg a többi a Jászság déli részét képviseli, a térképezés módszertana alapján ideértve Újszász, Szászberek és Tápiógyörgye határának egy részét is (1. ábra). 


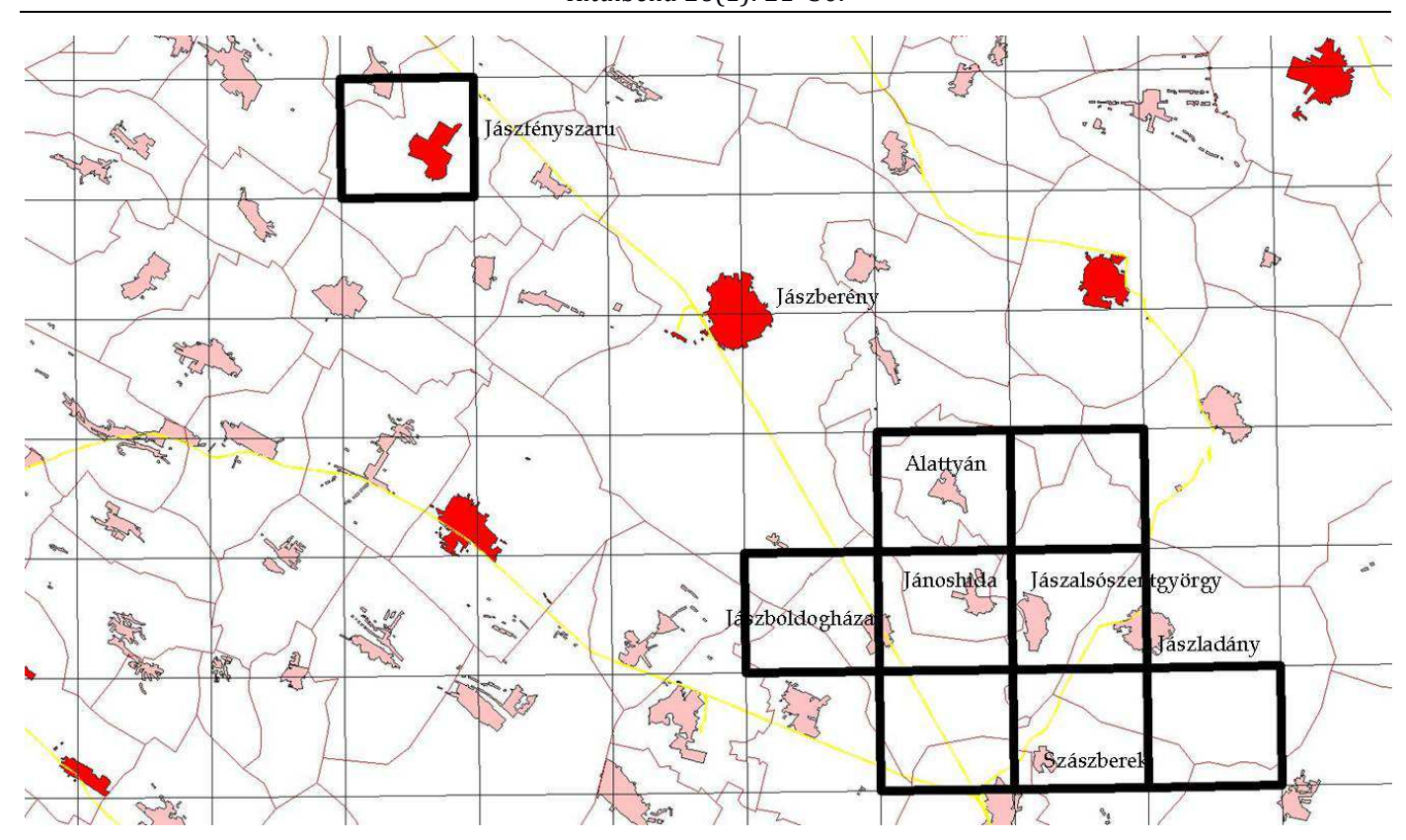

1. ábra A vizsgált terület térképe

Fig. 1 Map showing the study area

A felmérés viszonylag rövid idő alatt zajlott, arra törekedtem, hogy a módszertannak megfelelően kvadrátonként az összes jellemző élőhelyet bejárva, hozzávetőlegesen 300 fajt találjak (KIRÁLY et al. 2003). A gyüjtött adatok megtalálhatóak a Flóraatlaszban (BARTHA et al. 2015,2020 ). Ezek a flóralisták azonban hozzávetőlegesen 34,5 km²-es területekről készültek és indokoltnak tűnik, hogy a ritkább, vagy érdekesebb adatok pontosabban, részletesebben is közlésre kerüljenek. Néhány adat ellenőrzése céljából 2020. június 24-25-én ismét felkerestem a területek egy részét. Az ismételt terepbejárás során is találtam érdekesebb új előfordulásokat, melyeket szintén itt teszek közzé „(2020)” jelzéssel.

A terepmunka során SIMON (2000), KIRÁLY (2009), KIRÁLY et al. (2011) határozóit használtam. Az Enumerációban KIRÁLY (2009) sorszámait és nevezéktanát követem. Az adatok felsorolásánál először a településhatárt adom meg, majd a dűlőnevet, neveket. Szögletes zárójelben a vonatkozó flórakvadrát száma következik. Végül egyes esetekben az adatok értékelését, illetve az adott faj földrajzi elterjedésére vonatkozó utalásokat adok meg.

A mára döntően szántóvá alakított Jászság és közvetlen környezetének térképezése során a legnagyobb figyelmet az erdei flórának szenteltem. A kis kiterjedésű, sokszor részben, vagy egészben másodlagos erdők máig számos fajt őriznek. Ezek a területek a Zagyva és mellékvizei által szorosan kapcsolódtak a középhegységi erdőkhöz, de mára többségük elszigetelődött. Fontos élőhelyet jelentenek a táj mezsgyéi, melyek elsősorban a lecsapoló munkák során készült és ma is használatban lévő árkok partját jelentik. Ez utóbbiak sokszor erősen cserjésednek, tovább csökkentve az őshonos fajok túlélési esélyeit. Emellett szikes és üde gyepek, vizes élőhelyek, szántók, urbánus területek, vasút- és közútvonalak is gazdagították a flórát. Különös figyelmet érdemel az erdők közül a Jászalsószentgyörgyi Borsa-erdő a tőle északra lévő csatornaparttal az erdő egykori nagyobb kiterjedésű helyén (Kapitány-dűlő) és az alattyáni Berki-erdő, a gyepek közül a jászboldogházi Bóták-dűlő területén és a jászfényszarui Bugyogó-Borjú-járás területén lévő láposodó mocsárrét és a boldogi Surján sédbúzása, valamint az alattyáni Nagy-kút-lapos szikese, továbbá Jászboldogházán egy műút padkája, melyen 2020-ra több szikes faj is megtelepedett. 
A Jászság florisztikailag a mai napig alulkutatott terület. A viszonylag csekély számú publikációt kitűnően mutatja be BuSCHMANN (2001), ami mellett Pócs Tamás 1950-es évekbeli herbáriumi gyűjtései érdemelnek említést (E. VoJTKó et al. 2014). A közelmúlt kutatásai közül a flóratérképezés mellett a legfontosabb Buschmann Ferenc munkássága (BuschmANN 1995a, 1995b, 2001, 2013). Sajnos máig jórészt publikálatlan Nagy János és Tóth Zsuzsa kutatási eredményeinek többsége (NAGY et al. 2008, NAGY 2010, TóTH et al. 2014a, 2014b, 2015).

\section{Enumeráció}

219. Chenopodium chenopodioides (L.) Aellen: Jászboldogháza: jánoshidai út padkája (2020) [8686.1].

265. Amaranthus deflexus L.: Jászalsószentgyörgy: belterületi járdarepedésekben (2020) [8686.2]. - A mára országosan viszonylag gyakorivá vált idegenhonos fajnak eddig csak két jászsági adata volt ismert, Pusztamonostorról (TAKÁcs et al. 2016) és Jászladányból (Schmotzer A. flóratérképezési adata - BARTHA et al. 2020). Bizonyára gyakoribb.

273. Phytolacca americana L.: Újszász: Parkerdő [8686.4]. - Az Alföld jelentős részén mára közönségessé vált faj a vizsgált területen máig nem gyakori, még homokos talajokon sem.

274. Phytolacca esculenta van Houtte: Jászalsószentgyörgy: Vadaskert [8686.2]. Jászfényszaru: erdő a Galga-közben [8484.1]. - Az előzőnél ritkább faj, melynek terjedése a közelmúltban gyorsult fel (vö. BALOGH 2005, SCHMOTZER 2019b).

348. Silene bupleuroides L.: Jászboldogháza: Bóták-dűlő [8685.2]. Jászboldogháza-Újszász: Tápió-csatorna [8686.3]. Jászfényszaru: Bugyogó-Borjú-járás [8484.1]. - Országosan is ritka, védett faj.

418. Clematis integrifolia L.: Jánoshida: Zagyva-part [8686.2]. Jánoshida-Jászalsószentgyörgy: Jánoshidai-csatorna mellett [8686.1]. Jászalsószentgyörgy: Borsa-erdő és Jánoshidai-csatorna partja (2020) [8586.3, 8586.4, 8686.2]. Jászboldogháza-Szászberek: Holt-Zagyva (horgásztó) [8686.4]. Újszász: Parkerdő [8686.4]. Szászberek: Zagyva-part [8686.4]. - Itt is, ahogy az Alföld jelentős részén, populációi elsősorban árvízvédelmi töltéseken élnek. Védett faj.

423. Clematis recta L.: Jászalsószentgyörgy: Vadaskert [8686.2]. Jászboldogháza: Csíkoserdő [8686.3]. - A Zagyva menti erdők ritka faja. Az Északi-középhegységben még jellemző faj az Alföldön csak néhány ponton maradt fenn. A Jászságból korábban a jászdózsai Pap-erdőből jelezte AlmÁDI (1985), de az átalakuló erdőben fennmaradása bizonytalan, a Flóraatlasz szerint adata megerősítésre vár. Legközelebb a Gyöngyösi- és a Hevesi-sík néhány pontjáról SCHMOTZER (2019a) írja, félárnyékos helyekről, reliktumjellegű gyepekből és cserjésekből és ugyaninnen írja már Kitaibel is Tarnaörs és Heves határából (LőKÖs 2001). A Sajó-Hernád-síkon ismert még két erdei előfordulása Mezőcsát és Alsózsolca határában (TAKÁCS et al. 2013), valamint kettő a Turjánvidékről Ócsáról és Kunpeszérről (Kun A. és Máthé A. in CsÁKY 2018).

450. Ranunculus auricomus L. - Újszász: Parkerdő [8686.4]. - A középhegységben gyakori fajnak viszonylag kevés alföldi adata ismert, vagy maradt. A Hevesi-síkról ScHMOTzER (2019a) adja aktuális adatait, ezen túl legközelebb Hatvan (Mester Zs.), Kisújszállás (Majláth I.) és Tatárszentgyörgy mellől (Vidéki R. és Máté A. flóratérképezési adatai BARTHA et al. 2020) ismert. Kitaibel még gyüjtötte a Hevesi-erdőből, de mára kipusztult (JÁVORKA 1935).

462. Thalictrum minus L.: Jászboldogháza: a falu felett, a vasút mentén [8685.2]. Jászboldogháza-Tápiógyörgye: megyehatár mentén Koncsik-Jászberényi-határ között [8685.2]. - A löszös területek jellemző faja a Jászságban nem gyakori (pl. BuschmAnN 1995b). 
496. Sisymbrium strictissimum L.: Jászalsószentgyörgy: Borsa-erdő [8586.3, 8586.4, 8686.2]. - A kis Borsa-erdő 3 kvadrát metszéspontjában található. A jellegzetesen középhegységi faj a Flóraatlasz szerint csak néhány ponton ereszkedik le az Alföldre. Legközelebb Buschmann Ferenc, Bánkuti Károly és Mester Árpád gyűjtötte Jászfelsőszentgyörgy határában, Hajta menti mocsárszéli tölgyesben, 1998-ban (BusCHMANN 2013), valamint Schmotzer András jelezte a tarnaörsi flórakvadrátból (BARTHA et al. 2020). Közelebbi nagyobb állományai a Gödöllői-dombvidékről (Isaszeg mellől Szénási V. BARTHA et al. 2020) és a Mátraaljáról (Kápolna, valamint Nagyréde határából SRAMKó et al. (2008), Nagyút mellől Schmotzer A. - BARTHA et al. 2020) ismertek.

504. Myagrum perfoliatum L.: Jászboldogháza: Csíkos-tanyák [8686.1]. - A térségben még többfelé ismert, szórványos előfordulású, így Jászberényből (BusCHMANN 2013), Jászdózsáról (Vidéki R. flóratérképezési adata, valamint saját gyüjtés: Molnár Cs. in TAKács et al. 2014a), Jászszentandrás és Jászboldogháza határából (Schmotzer A. flóratérképezési adatai - BARTHA et al. 2020). Korábban Újszászról említette Boros Ádám (Soó \& MÁTHÉ 1938).

527. Rapistrum perenne (L.) All.: Jászladány-Szászberek: Nagy-kanális (100. sz. mellékcsatorna) magaspartján [8686.4]. - Nem találtam más adatát a Jászságból, de a szomszédos Mátraalján, Gyöngyösi-síkon, illetve Monor-Irsai-dombságban nem ritka.

601. Lepidium densiflorum Schrad.: Jászalsószentgyörgy: a falu déli végén lévő kamionparkolóban [8686.2]. Jászboldogháza: vasútállomás [8686.1] és vasúti sínek mentén [8686.3]. Jászladány: vasútállomás [8686.2]. - Elsősorban vasutak, másodsorban közutak mentén terjedő idegenhonos növény (pl. TAKÁCS et al. 2014b, SCHMOTZER 2015, MolNÁR et al. 2020).

603. Coronopus squamatus (Forssk.) Asch.: Alattyán: Kis-kút-lapos [8586.3, 8586.4].

635. Hylotelephium telephium (L.) H. Ohba subsp. maximum (L.) H. Ohba: Alattyán: Berkierdő [8586.3]. - A Crisicum területén feltűnően ritka fajnak (Molnár A. ex lit.) nem ismert más jászsági adata.

711. Sanguisorba officinalis L.: Boldog: Surján [8484.1]. Jászboldogháza: Bóták-dűlő [8685.2]. Jászfényszaru: Bugyogó-Borjú-járás; Naplás [8484.1].

759. Malus dasyphylla Borkh.: Jászalsószentgyörgy: Vadaskert [8686.2]. - Kevéssé ismert, bizonytalan taxon (BARTHA 2009), melyből néhány középkorú fa állt egy parkerdő jellegü, de akkor gondozatlan, bozótos kis erdőfoltban. Talán ültetett?

911. Lathyrus nissolia L.: Alattyán: Nagy-kút-lapos [8586.3, 8586.4].

941. Trigonella caerulea (L.) Ser.: Jászladány: vasútállomás, az állomás egykori rakodójának kőtörmelékes talaján [8686.2]. - Ritka, alkalmi kivaduló kultúrnövény, aminek csak nagyon szórványosan ismertek hazai szubspontán adatai (TöRöK et al. 2016, MATUS et al. 2019, MolnáR et al. 2020).

966. Trifolium angulatum W. \& K.: Alattyán: Nagy-kút-lapos [8586.3, 8586.4]. Jászboldogháza: Iványi-dülő [8685.2].

968. Trifolium retusum L.: Alattyán: Nagy-kút-lapos [8586.3, 8586.4]. Jászboldogháza: Iványi-dűlő [8685.2].

1015. Geranium dissectum Jusl.: Jászalsószentgyörgy: Borjú-járás, búzában (2020) [8686.1].

1026. Tribulus terrestris L.: Jászboldogháza: vasútállomás [8686.1]. Jászladány: vasútállomás [8686.2]. - A vasútvonalak mentén mára országosan elterjedt fajnak vannak őshonosnak tekintett, homoki előfordulásai is a tájban Tarnaörsön (ALMÁDI 1984) és az újerdői homokvidéken (BusCHMANN 2013).

1083. Acer tataricum L.: Jászalsószentgyörgy: Borsa-erdő [8586.3, 8586.4, 8686.2]. Jászfényszaru: erdő a Galga-közben [8484.1]. - A faj a kevés erdei túlélő egyike, egyben itt éri el elterjedésének déli határát az Alföld központi része felé. 
1165. Viola pumila Chaix: Alattyán: Kis-kút-lapos; Nagy-kút-lapos [8586.3, 8586.4].

1244. Eryngium planum L.: Jánoshida: Kerek-sás, kaszált gyepben [8686.1]. - A térségben szórványos (Soó \& MÁTHÉ 1938, AlMÁDI 1984, 1985, BusCHMANN 2013).

1291. Bupleurum affine Sadler: Jászalsószentgyörgy-Jászladány: Szászberki- (119. sz.-) csatorna mellett [8686.2]. - A Jászságban ritka faj legközelebb Szolnok és Cegléd határából ismert (Urbán S. és Drozd A. flóratérképezési adatai - BARTHA et al. 2020). A Monor-Irsai-dombságban már gyakoribb (SCHMOTZER \& VIDRA 1998).

1311. Peucedanum officinale L.: Alattyán: Berki-erdő tisztása [8586.3]. Jászalsószentgyörgy: Tehén-járás, kaszált gyepben; a Borsa-erdő tisztásain és a Jánoshidai-csatorna partján [8586.3, 8586.4, 8686.1, 8686.2]. - A sziki tölgyesek egyik karakterfaja, ami többek között itt is erdei tisztásokon él. A Berki-erdőből gyűjtötte 1998-ban Buschmann Ferenc és Bánkuti Károly (Buschmann 2013). Védett faj.

1312. Peucedanum alsaticum L.: Alattyán: Berki-erdő [8586.3]. Szászberek: Jászladányi út mentén [8686.4]. Újszász: Parkerdő [8686.4]. - A Jászságban szórványos fajnak (lásd pl. ALMÁDI 1985, BusCHMANN 2013) csak 6 flórakvadrátból ismert adata, főleg a térség északkeleti részéből. Az M3-as vonalától északra már gyakori, de attól délre csak a Hevesi-síkon jellemző, a Crisicum többi szomszédos területén ritka, vagy hiányzik.

1396. Vincetoxicum hirundinaria Medik.: Alattyán: Berki-erdő [8586.3]. Jászalsószentgyörgy: Borsa-erdő [8586.3, 8586.4, 8686.2]. Jászboldogháza-Újszász: Zagyva-gát [8686.3, 8686.4]. Jászfényszaru: erdő a Galga-közben [8484.1]. Jászladány-Szászberek: Nagy-kanális (100. sz. mellékcsatorna) [8686.4]. Újszász: Parkerdő [8686.4]. - A középhegységben még gyakori faj a Jászságban jobbára már csak a túlélő erdei flóra része.

1478. Teucrium scordium L.: Jászalsószentgyörgy-Jászladány: Határ-árok (Szászberki- [119. sz.] főcsatorna) [8686.4]. Szászberek: Zagyva-part [8686.4].

1488. Phlomis tuberosa L.: Jászalsószentgyörgy: Jánoshidai-csatorna partján a Kapitánydűlőnél (2020) [8586.4]. Szászberek: Jászladányi út mentén [8686.4]. - Védett faj.

1525. Melissa officinalis L.: Újszász: Parkerdő [8686.4]. - Szubspontán állomány, mely származhat a település kertjeiből, de propagulumát hozhatta a Zagyva is.

$\times \times \times \times$ Salvia $\times$ sylvestris L. $(S$. nemorosa L. $\times$ S. pratensis L.): Jászfényszaru: Galga-gát [8484.1]. - Szülőfajok környezetében egy tő.

1615. Linaria angustissima (Loisel.) Borbás: Tápiógyörgye: Külső-mező [8685.2].

1617. Linaria biebersteinii Besser: Jászalsószentgyörgy: Jánoshidai-csatorna partján a Kapitány-dúlőnél (2020) [8586.4]. - A faj feltúnően ritkább, mint a flórajárás tiszántúli részén (Molnár A. ex lit.), a Jászságban csak 3 korábbi adatát találtam, Nagy János flóratérképezési adatait Jászberényből, Jászjákóhalmáról és Jászapátiból (BARTHA et al. 2020). Védett faj.

1633. Veronica anagalloides Guss.: Alattyán: Jánoshidai-csatorna mellett [8586.3, 8586.4].

1724. Galium rubioides L.: Alattyán-Jánoshida-Jászalsószentgyörgy-Jászboldogháza-Szászberek: Zagyva-part. Jászalsószentgyörgy: Tehén-járás, kaszált gyepben, Borsa-erdő, Borsa- és Kapitány-dúlő közepén húzódó árok partján (2020 - 8586.4), Jánoshidaicsatorna partja (2020 - 8586.4). Jászboldogháza: Csíkos-második-dúlő, kaszált gyepben. Jászboldogháza-Újszász: Tápió-csatorna. Jászfényszaru: Bugyogó-Borjú-járás. [8484.1, 8586.3, 8686.1, 8686.2, 8686.2, 8686.3, 8686.4] - Elsősorban árvízvédelmi töltéseken.

1752. Plantago maritima L.: Jászboldogháza: jánoshidai út padkája (2020) [8686.1].

1829.1 Aster sedifolius L. subsp. sedifolius: Alattyán: Kis-kút-lapos; kis gyep a Kun ere torkolata mellett; Berki-erdő tisztása. Besenyszög: Nagy-kanális. Besenyszög-Jászladány: Határ-árok (102. sz. mellékcsatorna). Jászalsószentgyörgy: Tehén-járás, kaszált gyepben; a Borsa-erdő tisztásain. Jászalsószentgyörgy-Szászberek: 32-es út mellett. Jász- 
boldogháza: Tápió (nem a folyó, hanem a határrész). Jászladány-Szászberek: Nagykanális (100. sz. mellékcsatorna). Szászberek: Daru-hát; Jászladányi út mentén. Újszász: Parkerdő. [8586.3, 8586.4, 8686.1, 8686.2, 8686.3, 8686.4, 8687.3]. - Védett faj.

1856. Inula germanica L.: Jászalsószentgyörgy: Borsa-erdő tisztásain, szélén, Jánoshidaicsatorna partján a Kapitány-dűlőnél (2020), valamint a Borsa- és Kapitány-dűlő közepén húzódó árok partján (2020) [8586.4, 8686.2]. - Védett faj.

1857. Inula salicina L.: Jászalsószentgyörgy: Borsa-erdő [8586.4, 8686.2]. - A Jászságban nem gyakori.

1923. Artemisia santonicum L.: Jászboldogháza: jánoshidai út padkája (2020) [8686.1].

1929. Artemisia pontica L.: Besenyszög: Nagy-kanális. Besenyszög-Jászladány: Határ-árok (102. sz. mellékcsatorna). Jászalsószentgyörgy: 32-es út mellett; Borsa-erdő tisztásain, Borsa- és Kapitány-dűló közepén húzódó árok partján (2020), Jánoshidai-csatorna partján a Kapitány-dúlőnél (2020). Jászladány: Millér (Mély-ér). JászladánySzászberek: Nagy-kanális (100. sz. mellékcsatorna). Szászberek: Daru-hát; FelsőSzászberek. [8586.4, 8686.1, 8686.2, 8686.4, 8687.3]. - A Crisicumban általában gyakori fajnak csak kevés adata ismert a Jászságból, ami lehet, hogy csupán a kutatatlanság eredménye.

1957. Senecio doria Nath.: Alattyán-Jászalsószentgyörgy: Jánoshidai-csatorna mellett. Boldog-Jászfényszaru: Pap-árok mentén. Jászboldogháza: Tápió-gát. JászboldogházaSzászberek: Holt-Zagyva (horgásztó). Jászfényszaru: Galga-gát. Szászberek: 32-es út mellett. [8484.1, 8586.4, 8686.3, 8686.4].

2008.1 Centaurea scabiosa L. subsp. sadleriana (Janka) Asch. \& Graebn.: Alattyán-Jászalsószentgyörgy: Jánoshidai-csatorna mellett. Besenyszög-Jászladány: Határ-árok (102. sz. mellékcsatorna). Jánoshida: 32-es út szélén, Jánoshida és Jászalsószentgyörgy között; Jászalsószentgyörgy: Borsa-erdő tisztásain. Jászboldogháza-Újszász: Zagyva-gát. Jászfényszaru: Galga-gát. Jászladány: Millér (Mély-ér). Jászladány-Szászberek: Nagykanális (100. sz. mellékcsatorna). Jásztelek: Szentgyörgyi út mentén, mezsgyében. Szászberek: Jászladányi út mentén; Felső-Szászberek; vasútállomás. [8484.1, 8586.3, 8586.4, 8686.1, 8686.2, 8686.3, 8686.4, 8687.3] Egy populációja átmeneti bélyegeket mutat a törzsalak felé: Jászboldogháza: tápiógyörgyei út mentén [8685.2]. - Gyakori. A C. scabiosa fajcsoportnak a Crisicumban a Tiszától nyugatra jórészt ezzel a képviselőjével találkozhatunk, míg a Tiszától keletre már a subsp. scabiosa jellemző. Védett alfaj.

2024. Podospermum canum (C.A. Mey.) Griseb: Jászboldogháza: jánoshidai út padkája (2020) [8686.1].

2047. Taraxacum bessarabicum (Hornem.) Hand-Mazz.: Jászladány: Kocsis-dűlő, régi juhlegelő maradványán [8687.3]. - A szikesedő legelőkhöz kötődő faj az év nagy részében nehezen felismerhető, talán emiatt is kevés adatát ismerjük. Jászárokszállásról írja Kitaibel, Jászkisérről és Szászberekről Moesz (Soó \& MÁtHé 1938).

2155. Ornithogalum brevistylum Wolfner: Alattyán: Kis-kút-lapos; Berki-erdő. JánoshidaJászalsószentgyörgy: Jánoshidai-csatorna mellett; Jászalsószentgyörgy: Borjú-járás; Fűzfa-dűlő és Csicsó-dűlő között; Zöld-halom-dűlő, Borsa- és Kapitány-dúlő közepén húzódó árok partján (2020) mezsgyékben. Jászladány: Besenyszögi út mentén; Császár-dűlő és Orbai-dűlő, vasúti sínek mellett; Kocsis-dűlő; Millér (Mély-ér). Szászberek: vasútállomás mellett [8586.3, 8586.4, 8686.1, 8686.2, 8686.3, 8686.4, 8687.3]. Gyakori. Védett faj.

2184. Allium atropurpureum W. \& K.: Jászalsószentgyörgy: Fűzfa-dűlő és Csicsó-dűlő között, mezsgyében [8686.4]. Jászalsószentgyörgy-Jászladány: Határ-árok (Szászberki[119. sz.] fő́csatorna) [8686.4]. Jászboldogháza-Újszász: Zagyva-gát [8686.3]. - Szórványosan mezsgyéken és gátakon fordul elő. A Jászságban ritka, fố elterjedési területe 
a Tiszántúl déli részére esik. Előkerült a jászdózsai Pap-erdő szélén, ahol Buschmann Ferenc gyűjtötte 1998-ban (BuschmanN 2013), valamint Jásziványban (Schmotzer A. flóratérképezési adata - BARTHA et al. 2020), Tápiószelén (Kovács D. in CSIKY et al. 2018), Zagyvarékason, majd Szolnok környékén már gyakoribb (Urbán S., Drozd A. és Horváth D. flóratérképezési adatai - BARTHA et al. 2020).

2186. Allium angulosum L.: Boldog: Surján [8484.1]. Boldog-Jászfényszaru: Pap-árok mentén [8484.1]. Jászboldogháza: Tápió-csatorna és a régi meder között [8686.3].

2191. Convallaria majalis L.: Jászalsószentgyörgy: Borsa-erdő [8586.4, 8686.2]. Újszász: Parkerdő [8686.4].

2219. Najas marina L.: Jászboldogháza-Újszász: Tápió-csatorna [8686.3]. Jászfényszaru: Galga; Zagyva [8484.1].

2253. Iris spuria L.: Alattyán: Kis-kút-lapos; Berki-erdő tisztása [8586.3, 8586.4]. Jászalsószentgyörgy: Borsa-erdő tisztásain [8586.3, 8586.4, 8686.2]. Jászboldogháza: Csíkosmásodik-dúlő, kaszált gyepben [8686.1]. - Védett faj.

2276. Juncus tenuis Willd.: Jászboldogháza: Csíkos-erdő; Csíkos-tanyák, csatornapartokon és gyepekben [8586.3, 8685.2, 8686.1, 8686.3]. - Terjedőben.

2322. Vulpia myuros (L.) C.C. Gmel. - Jászboldogháza: Jászboldogháza-Jánoshida vasútállomás (2020) [8686.1].

2356. Melica transsilvanica Schur: Jászalsószentgyörgy: Fűzfa-dűlő északi határárka mellett [8686.2]. Jászalsószentgyörgy-Jászladány: Szászberki- (119. sz.-) csatorna mellett [8686.2]. Jászboldogháza: Csíkos-erdő [8686.3]. - A faj a Jászságban a keleti areaperemét éri el, délkelet felé már csak néhány szórvány előfordulásával találkozhatunk (Molnár A. ex lit.).

2357. Melica altissima L.: Alattyán: Berki-erdő [8586.3]. Jászalsószentgyörgy: Borsa-erdő [8586.3, 8586.4] (2020 - 8686.2). Szászberek: Nagy-kanálistól délre lévő telepített kocsányos tölgyesben [8687.3]. - Tarnaörs határából már Kitaibel is feljegyezte (LőKös 2001), majd Jászdózsáról JANKA (1866) és később ALMÁDI (1985), vélhetően mindhárman ugyanabból a flórakvadrátból, ahol ma is él (Albert É. és Schmotzer A. flóratérképezési adata - BARTHA et al. 2020).

2393. Elymus caninus (L.) L.: Alattyán: Berki-erdő [8586.3]. Jászalsószentgyörgy: Borsaerdő (2020) [8586.3, 8586.4, 8686.2]. - A Jászságban ritka erdei faj.

2394. Elymus elongatus (Host) Runemark: Jászfényszaru: Naplás [8484.1]. - Szántóföldi kultúra és körötte szubspontán egyedek árokparton, bokorsor tövében, ruderális helyeken.

2397. Agropyron cristatum (L.) Gaertn.: Jászalsószentgyörgy: Borjú-járás, mezsgyében [8686.1]. Szászberek: vasúti hídfó a Zagyván [8686.4].

2398. Aegilops cylindrica Host: Jászalsószentgyörgy: Jánoshidai-csatorna mellett, Kapitánydúlőben, repce szélén (2020) [8586.4]. Szászberek: vasútállomás melletti szántó szélén [8686.4]. - A szászberki adatot feldolgozták TÁBORSKÁ et al. (2015) is, de hibásan, a 8787.4-es kvadrátra hivatkozva.

2410. Hordeum hystrix Roth: Jászboldogháza: jánoshidai út padkája (2020) [8686.1].

2464. Alopecurus myosuroides Huds.: Jászalsószentgyörgy: Borsa-dűlő, szántón, búza, napraforgó és kukorica alatt (2020) [8586.4, 8686.2].

2489. Eragrostis cilianensis (All.) Vignolo ex Janch.: Jászfényszaru: Köves-part [8484.1].

2499. Tragus racemosus (L.) All.: Jászboldogháza: vasútállomás [8686.1]. Jászfényszaru: Boldogi út; vasútállomás; Galga-híd Homok-erdő felé [8484.1]. Jászladány: vasútállomás [8686.2]. Szászberek: vasútállomás [8686.4]. - Figyelemre méltó, hogy Buschmann Ferenc és Bánkuti Károly 2004-ben, Tóalmáson nem vasút, vagy közút mellől gyüjtötte, hanem gyepből (BuschmAnN 2013). 
2518. Sorghum halepense (L.) Pers.: Jánoshida: 32-es út szélén, Jánoshida és Jászalsószentgyörgy között; Jászboldogháza: Csíkos-első-dűlő, csatornaparton; Tápió-csatorna és a régi meder között; vasút mentén. Jászfényszaru: vasútállomás és város közötti út mellett. Szászberek: Daru-hát; Jászladányi út mentén. Tápiógyörgye: Ebecki. [8484.1, 8685.2, 8686.1, 8686.3, 8686.4] - Az akkor még csak terjedő növény, mára gyakorivá vált.

2650. Carex secalina Wahlenb.: Jászboldogháza: Csíkos-tanyák, csatornapartokon és gyepekben [8686.1].

\section{Köszönetnyilvánítás}

Köszönettel tartozom Buschmann Ferencnek, aki még az 1990-es évek végén megosztotta velem kéziratát, Bartha Dénesnek és Király Gergelynek a Flóratérképezési Program szervezéséért, valamint Csathó András Istvánnak a kézirathoz füzött néhány hasznos megjegyzéséért. Külön köszönet illeti Molnár Attilát a kézirathoz füzött építő lektori kritikája miatt.

\section{Irodalom}

ALMÁDI L. (1984): Adatok Tarnaörs környékének flórájához. - Folia Historico-naturalia Musei Matrensis 9: $15-17$.

AlMÁDI L. (1985): Adatok az Észak-Jászság flórájához. - Folia Historico-naturalia Musei Matrensis 10: 25-30.

BALOGH L. (2005): A Phytolacca esculenta van Houtte szelíd inváziója a magyarországi településflórában. - Flora Pannonica 3: 135-161.

BARTHA D. (2009): Rosaceae [incl. Amygdalaceae, Malaceae, Spiraeaceae] - Rózsafélék családja. - In: KIRÁLY G. (szerk.), Új magyar füvészkönyv. Aggteleki Nemzeti Park Igazgatóság, Jósvafő, pp. 200-234.

BARTHA D., BÁN M., SCHMidT D. \& TiBoRCZ V. (2020): Magyarország edényes növényfajainak online adatbázisa (http://floraatlasz.uni-sopron.hu) - Soproni Egyetem, Erdőmérnöki Kar, Növénytani és Természetvédelmi Intézet. (Hozzáférés: 2020.07.01.)

BARTha D., KirÁly G., Schmidt D., TiborCZ V., BARina Z., CSIKY J., JAKAB G., LeSKu B., SChMotZer A., VidÉKi R., Vojткó A. \& Zólyomi Sz. (szerk.) (2015): Magyarország edényes növényfajainak elterjedési atlasza. Nyugat-Magyarországi Egyetem Kiadó, Sopron, 329 pp.

Buschmann F. (1995a): Jászberény és környékének növényvilága. I. Természetföldrajzi élettér. - kézirat, Jászberény, $32 \mathrm{pp}$.

BuschmanN F. (1995b): Jászberény és környékének természeti értékei. I. A Hajta. - Jászsági Füzetek 22. Jász Múzeum, Jászberény, 178 pp.

BuschmanN F. (2001): Jászberény és környékének növényvilága (I. Természet- és növényföldrajzi viszonyok). - Tisicum 12: 27-48.

Buschmann F. (2013): A jászberényi Jász Múzeum növénygyüjteménye. - Tisicum 22: 259-291.

CsÁKY P. (2018): A Turjánvidék északi részének florisztikai szempontból jelentős növényfajai. - In: Korda M. (szerk.), Természetvédelem és kutatás a Turjánvidék északi részén. - Rosalia 10: 145-252.

Csiky J., BARÁth K., Csikyné R. É., Deme J., Wirth T., Zurdo J. A. \& KovÁcs D. (2018): Pótlások Magyarország edényes növényfajainak elterjedési atlaszához VIII. - Kitaibelia 23(2): 238-261.

E. VojtKó A., TAKÁcs A., MolnáR V.A. \& VojtKó A. (2014): Herbarium database of the vascular collection of Eszterházy Károly College (EGR). - Kitaibelia 19(2): 339-348.

JANKA V. (1866): Neue Standorte ungarischer Pflanzen. - Oesterreichische Botanische Zeitschrift 16: 169172.

JÁvorKa S. (1935): Kitaibel herbáriuma IV. (Herbarium Kitaibelianum IV). - Annales Musei historiconaturalis hungarici 29: 55-102

KIRÁLY G. (szerk.) (2009): Új Magyar Füvészkönyv. Magyarország hajtásos növényei. Határozókulcsok. Aggteleki Nemzeti Park Igazgatósága, Jósvafö, 616 pp.

Király G., Balogh L., Barina Z., Bartha D., Bauer N., Bodonczi L., Dancza I., Farkas S., Galambos I., Gulyás G., Molnár V. A., Nagy J., Pifkó D., Schmotzer A., Somlyay L., Szmorad F., Vidéki R., VojtKó A. \& Zólyomi Sz. 
(2003): A magyarországi flóratérképezés módszertani alapjai. Útmutató és magyarázat a hálótérképezési adatlapok használatához. - Flora Pannonica 1(1): 3-20.

Király G., ViróK V. \& MolnáR V. A. (szerk.) (2011): Új Magyar Füvészkönyv. Magyarország hajtásos növényei. Ábrák. - Aggteleki Nemzeti Park Igazgatósága, Jósvafő, 679 pp.

LőKös L. (szerk.) (2001): Diaria Itinerum Pauli Kitaibelii III. - Magyar Természettudományi Múzeum, Budapest, $459 \mathrm{pp}$.

Matus G., Aszalós R., Dorotovič Cs., Hanyicska M., Hüvös-Récsi A., Musicz L., MiglÉcz T., PAPP M., Schmotzer A., TöRÖK P., VALKó O., VojTKó A., HARTMANN J., TAKÁcs A. \& BALOGH R. (2019): Kiegészítések a magyar flóra ismeretéhez. - Botanikai Közlemények 106(1): 71-112.

Molnár Cs., Bauer N., Csathó A. I., Szigeti V. \& Schmidt D. (2020): Az Oenothera pycnocarpa Atk. \& Bartl. Magyarországon, és kiegészítések néhány idegenhonos faj hazai elterjedéséhez. - Botanikai Közlemények 107(2): 177-202.

Nagy J. Gy., Tóth Zs., Fogarasi G. \& Cserhalmi D. (2010): Data to the flora and vegetation of Jászság microregion (Hungary). - In: BotTA-DuKÁt Z., SALAMON-AlBert É., PÁL R., NYULASI J., CSIKY J. \& LENGYEL A. (eds), Flora, vegetation, environment and land-use at large scale: 19th International Workshop of European Vegetation Survey Pécs, Magyarország. Department of Plant Systematics and Geobotany University of Pécs, p. 111.

NAGY J., URBÁN S. \& TóTH T. (2008): 1.7.15 Jászság. - In: KiRÁLY G., MolnÁR Zs., BölÖNI J., CSIKY J. \& VojTKó A. (szerk.), Magyarország földrajzi kistájainak növényzete. MTA ÖBKI, Vácrátót, p. 46.

Schmotzer A. (2015): Ceratocephala testiculata (Crantz) Roth és további adatok a Bükkalja flórájához. Kitaibelia 20(1): 81-142.

Schmotzer A. (2019a): Adatok a Heves-Borsodi-sík flórájához I. Erdei, erdőssztyepp- és sztyeppfajok elterjedése. - Kitaibelia 24(1): 16-65.

Schmotzer A. (2019b): New localities of Eleusine indica (Poaceae) and Phytolacca esculenta (Phytolaccaceae) in Eastern Hungary. - Studia botanica hungarica 50(1): 121-134.

SchmotZer A. \& VIDRA T. (1998): Flórakutatás a Monor-Irsai-dombság löszvidékén. - Kitaibelia 3(2): 321-328.

Simon T. (2000): A magyarországi edényes flóra határozója. - Nemzeti Tankönyvkiadó, Budapest.

Soó R. \& MÁTHÉ I. (1938): A Tiszántúl flórája. Flora Planitiei Hungariae Transtibiscensis. - Editio Instituci Botanici Universitatis Debreceniensis, $192 \mathrm{pp}$.

SRAmKó G., MAGos G., MolnÁr Cs. \& URBÁN L. (2008): Adatok a Mátra és környéke edényes flórájának ismeretéhez. - Kitaibelia 13(1): 74-93.

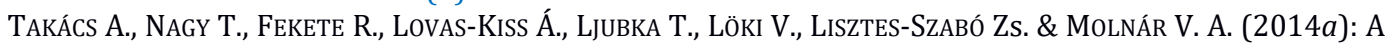
Debreceni Egyetem Herbáriuma (DE) I.: A „Soó Rezső Herbárium”. - Kitaibelia 19(1): 142-155.

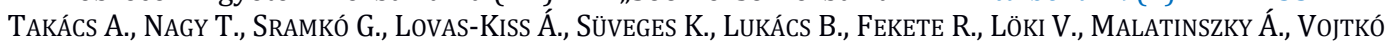
A., Koscsó J., Pfliegler W., Nótári K., Molnár V. (2016): Pótlások Magyarország edényes növényfajainak elterjedési atlaszához I. - Kitaibelia 21(1): 101-115.

TAKÁCS A., SCHMOTZER A. \& SulYoK J. (2013): Florisztikai adatok a Sajó-Hernád-sík területéről. - Kitaibelia 18(1-2): 73-88.

TAKÁCS A., ZÁKÁNy A., Gulyás G., Koscsó J. \& SRAmkó G. (2014b): Florisztikai adatok a Tiszántúl északi pereméről. - Kitaibelia 19(2): 275-294.

TÁborská J., Vojtкó A., Dulai S. \& Schmotzer A. (2015): Distribution of Aegilops cylindrica Host in Hungary. - Thaiszia 25(1): 41-72.

Tóth Zs., Kerényi-Nagy V., Fogarasi G., Endrédi A., Kissné Uzonyi Á., Tolnai M., Pócs T., Molnár Cs., Buschmann F. \& JuHÁsz T. (2015): A Jászság kistérség edényes flórája, különös tekintettel a Rosaceae fajokra. - In: Kerényi-NAGY V., Szirmai O., Helyes L., Penksza K. \& NemÉNyI A. (szerk.), "I. Rózsa- és Galagonya-konferencia a Kárpát-medencében": nemzetközi konferencia: konferencia-kötet. Gödöllő, Szent István Egyetem, Egyetemi Kiadó, pp. 212-213.

Tóth Zs., NAGY J., FogARASI G., ENDRÉDI A. \& KISSNÉ UZONYI Á. (2014a): Flora survey in Jászság micro region, Hungary. - In: ČARNi A., JuvAN N. \& RiBeiRo D. (eds), 23rd International Workshop of the Europaean Vegetation Survey: Book of Abstract. - Ljubljana, Szlovénia: Zalozba ZRC, p. 105.

TóTH Zs., NAGY J. Gy., FogARASI G., KISSNÉ UZONYI Á. \& ENDRÉDI A. (2014b): Florisztikai adatok a Jászság kistáj és -kistérség területéről. - In: Schmidt D., Kovács M. \& BARTHA D. (szerk.), X. Aktuális Flóra- és Vegetációkutatás a Kárpát-medencében. Összefoglalók. Sopron, Nyugat-magyarországi Egyetem Erdőmérnöki Kar, p. 223. 
TöröK P., Tóth E., Tóth K., Valkó O., DeÁk B., Kelbert B., BÁlint P., Radócz Sz., Kelemen A., Sonkoly J., Miglécz T., Matus G., Takács A., Molnár V.A., Süveges K., Papp L., PAPP Jr. L., Tóth Z., BaKtay B., Málnási Csizmadia G., Oláh I., Peti E., Schellenberger J., Szalkovszki O., Kiss R. \& Tóthmérész B. (2016): New measurements of thousand-seed weights of species in the Pannonian flora. - Acta Botanica Hungarica 58(1-2): 187-198.

Beérkezett / received: 2020. 07. 09. • Elfogadva / accepted: 2020.12.13. 